\title{
Low impact of climate change on subalpine grasslands in the Swiss Northern Alps
}

\author{
Vittoz Pascal ${ }^{1,2}$, Randin Christophe ${ }^{2}$, Dutoit Annelise ${ }^{3}$, Bonnet François ${ }^{4} \& \mathrm{Hegg} \mathrm{Otto}^{5}$ \\ ${ }^{1}$ University of Lausanne, Faculty of Geosciences and Environment, Bâtiment Biophore, 1015 \\ Lausanne, Switzerland \\ ${ }^{2}$ University of Lausanne, Department of Ecology and Evolution, Faculty of Biology and \\ Medicine, Bâtiment Biophore, 1015 Lausanne, Switzerland \\ ${ }^{3}$ Ch. du Molard 3, 1805 Jongny, Switzerland \\ ${ }^{4}$ La Thomasia, Jardin alpin de Pont de Nant, 1880 Les Plans-sur-Bex, Switzerland \\ ${ }^{5}$ University of Berne, Geobotanical Institute, Altenbergrain 21, 3013 Bern, Switzerland.
}

Keywords: biological traits, community change, competition, correspondence analysis, ecological indicator value, facilitation, global warming, pasture abandonment, Switzerland

Corresponding author: Vittoz Pascal, University of Lausanne, Department of Ecology and Evolution, Faculty of Biology and Medicine, Bâtiment Biophore, 1015 Lausanne, Switzerland, fax + 412169242 65, e-mail pascal.vittoz@,unil.ch

Running title: Climate change and subalpine grasslands

\begin{abstract}
While phenological shifts and migration of isolated species under climate change have already been observed on alpine summits, very few studies have focused on community composition changes in subalpine grasslands. Here we use permanent plots monitored since 1954 and precisely located phytosociological censuses from 1970 to study compositional changes of subalpine grasslands in two distinct regions of the Swiss Northern Alps. In both areas, warming trends during the monitoring period were associated with changes in land management (abandonment of goat and sheep pasturing or grazing replaced by mowing). Old and recent inventories were compared with correspondence analyses (CA). Ecological indicator values, community-affinities and biological traits of the species were used to infer the factors responsible for triggering the observed changes. In both regions, subalpine grasslands were stable with smaller changes than have previously been observed in alpine environments. Only a few species appeared or disappeared and changes were generally limited to increasing or decreasing frequency and cover of certain taxa. At one site, grazing abandonment favoured fallow species. Some of these species were located at their upper altitudinal distribution limits and may have spread because of rising temperatures. In both areas, declining species were predominantly alpine and low growing species; their decline was probably due to increased competition (e.g., shade) with more vigorous subalpine taxa no longer limited by grazing. We conclude that vegetation communities can respond rapidly to warming as long as colonisation is facilitated by available
\end{abstract}


space or structural change. In the subalpine grasslands studied, changes were mainly driven by land management. These communities have a dense vegetation cover and newly arriving herbaceous species preferring warmer conditions may take some time to establish themselves. However, climate disturbances, such as exceptional drought, may accelerate community changes by opening gaps for new species.

\section{Introduction}

Climate warming will induce plant migration toward higher altitudes and more northern latitudes. Upward shifts of the treeline ecotone have been documented since the end of the Little Ice Age (e.g., Kullman 2001; Camarero \& Gutierrez 2004; Vittoz et al. 2008a) and increases in species richness in alpine and subnival vegetation in the Alps have been observed (e.g., Braun-Blanquet 1957; Braun-Blanquet 1975; Hofer 1992; Grabherr et al. 1994; Walther et al. 2005a; Vittoz et al. 2006; Pauli et al. 2007; Vittoz et al. 2008b). Similar changes have been recorded in arctic ecosystems, with a northward shift of the treeline ecotone (D'Arrigo et al. 1987), invasion of shrubs into former tundra vegetation and increasing plant biodiversity in mountain areas (Klanderud \& Birks 2003; Tape et al. 2006). In warmer conditions, migration has been observed for plant species like mistletoe (Viscum album) in the Swiss Central Alps (Dobbertin et al. 2005) and Ilex aquifolium in the undergrowth of Danish and Swedish forests (Walther et al. 2005b).

Numerous studies modeled plant distributions in mountain areas to predict future distribution and potential extinction risk (e.g., Guisan \& Theurillat 2000; Dirnböck et al. 2003). However, since plant species are expected to shift their ranges individualistically under changing climatic conditions (Huntley 1991), species distribution models (SDM; Guisan \& Thuiller 2005) based solely on abiotic correlations of current distributions may fail to predict future species distributions in altered biotic environments (Guisan \& Zimmermann 2000; Pearson \& Dawson 2003; Randin et al. 2006). In fact, only a few studies have incorporated mechanistic rules of biotic interactions such as interspecific competition or facilitation (Silvertown et al. 1992; Dullinger et al. 2005), although their importance has been proven experimentally (Theodose \& Bowman 1997). Choler et al. (2001) demonstrated that facilitation in alpine plant communities apparently allows species from lower elevations to move up the slope. Conversely, Dullinger et al. (2005) found that pine negatively affects the recruitment of spruce and larch at the edge of the subalpine zone, suggesting that plant-plant interactions may decrease the rate of species migration during climate warming. Callaway et al. (2002) showed that competition dominates interactions in the subalpine belt, while positive interactions are more important in the alpine belt.

Rapid increases in biodiversity and species turnover reported in alpine to subnival communities during the last century (e.g., Braun-Blanquet 1957; Grabherr et al. 1994; Walther et al. 2005a) may be promoted by high levels of invasion susceptibility of communities with ample available space in open vegetation, mainly structured by facilitative interactions. In contrast, subalpine grasslands may be much more resistant to invaders (e.g., Dullinger et al. 2003). In these dense plant communities, opportunities for potential immigrants to establish themselves may depend on disturbances (Burke \& Grime 1996).

In the European Alps, anthropogenic activities have modified vegetation for 5,000 years (e.g., Tinner \& Theurillat 2003). Fire and grazing (cattle, goat, and sheep) in subalpine belts have lowered the treeline ecotone and strongly influenced species distribution. However, cattle activity 
has been decreasing since around 1850-1900 (Bätzing 1991). Many pastures are abandoned and trees are recolonising subalpine grasslands (e.g., Motta \& Nola 2001; Vittoz et al. 2008a). This induces species distribution shifts, which are superimposed on top of the possible climate warming impact. On this basis, Körner (2005) suggested that this grassland abandonment will outweigh climate change impacts on mountain vegetation.

Whereas many studies have measured the phenology or growth of individual species under natural or experimental conditions (e.g., van Wijk et al. 2004; Hollister et al. 2005a; Sebastia 2007) or monitored plant migration in open alpine and subnival vegetation (e.g., Walther et al. 2005a; Pauli et al. 2007), only a few have focused on climate change impacts on species composition of subalpine grasslands (Price \& Waser 2000). Here we used permanent plots from the Schynige Platte, among the oldest in Switzerland (Hegg 1992), in combination with rerecorded precisely localized censuses in the Vallon de Nant, to analyse changes in plant composition and dominance of subalpine grasslands during the second half of the $20^{\text {th }}$ century. We hypothesized that changes driven by climate warming were less pronounced in these grasslands as compared to open alpine and subnival communities, due to higher plant density and hence lower invasion susceptibility, and that observed changes were mostly linked to land-use management.

\section{Location and methods}

\section{Study sites}

Both study sites are located in the Northern Alps biogeographical region of Switzerland (Fig. 1). Annual precipitation is around $1,600 \mathrm{~mm}$ (Vallon de Nant, $46^{\circ} 14^{\prime} \mathrm{N}, 7^{\circ} 06^{\prime} \mathrm{E}$, below designated by Nant, and Schynige Platte, $46^{\circ} 39^{\prime} \mathrm{N}, 7^{\circ} 55^{\prime} \mathrm{E}$, below designated by Schynige), regularly distributed throughout the year (Zimmermann \& Kienast 1999).

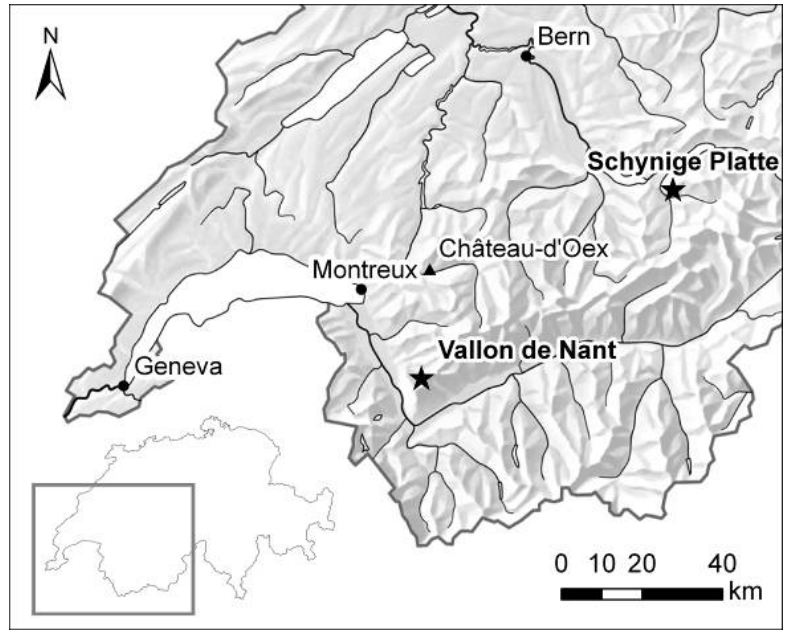

Fig. 1 Location of the study sites in Switzerland (Vallon de Nant and Schynige Platte), the Château-d'Oex meteorological station and some important towns. 
The two study sites belong to the subalpine belt and are naturally dominated by Picea abies forests, which have been frequently converted into pasture for cattle breeding for hundreds of years. The plots in Nant are situated along a small valley, between 1,370 and 1,815 $\mathrm{m}$ a.s.1., covering the overall altitudinal gradient of the subalpine belt. The approximate mean annual temperature ranges between 3.5-5.3 ${ }^{\circ} \mathrm{C}$ (Zimmermann \& Kienast 1999). In Schynige, all the plots are clustered in a small research area $(0.3 \mathrm{ha})$ at $1,920 \mathrm{~m}$ a.s.1., at the upper limit of the subalpine level. The mean annual temperature is $1.8^{\circ} \mathrm{C}$ (Zimmermann \& Kienast 1999).

Nant was previously grazed by cattle, goats and sheep. Goat and sheep breeding was seriously reduced in 1940 and abandoned in 1970 (Dutoit 1983). The slopes, considered in this study, are now only grazed by wild chamois (Rupicapra rupicapra) or are slowly colonised by Alnus viridis and Acer pseudoplatanus, except in avalanche pathways. Cattle are still grazing the flat parts of the valley (not considered here because of the absence of old data). Schynige was also grazed by cattle in the past, but the research area was fenced in 1930 (Lüdi 1936). The fences were given up in 1956 and cattle grazed the area until 1975 when fences were re-erected. Since then, the experimental area has been mowed every other year.

Annual mean temperature, as measured by the meteorological station in Château-d'Oex (MeteoSwiss; 980 m a.s.l., Fig. 1), has shown a strong increase since around 1970 (App. 1 in supplemental archives). In the $20^{\text {th }}$ century, Rebetez $\&$ Reinhard (in press) observed a temperature increase of $1.37^{\circ} \mathrm{C}$ in Switzerland, i.e., twice the increase in the Northern Hemisphere, and a mean temperature increase of $0.57^{\circ} \mathrm{C}$ per decade since 1975 .

\section{Field samplings}

The vegetation of Nant was described by Dutoit (1983), based on a set of vegetation censuses following the method of Braun-Blanquet (Braun-Blanquet 1964). The plots were not marked in the field but the geographic coordinates were precisely measured on a 1:10,000-map and accurately drawn irregularities on the map (gullies, very large stones, or groups of trees) helped to locate the plots. Our study used a subset of plots in the two dominant grassland types of the subalpine belt. Both types are confined to calcareous substrates and share many species, but Seslerion albicantis occupies the driest slopes (mainly on the south-facing or very steep slopes) whereas Caricion ferrugineae prefers more shady sites or moister soils. All but two of the plots were first sampled between July and September of 1970; the two others were sampled in 1969 and 1978 respectively).

In 2006, we re-located the plots by means of a Global Positioning System (GPS, Trimble GeoXT) receiver. The coordinates documented by Dutoit (1983) were defined as the centre of a circle with a radius of $30 \mathrm{~m}$. Within this circle, we selected a site of the same size as the original plot (usually $10 \mathrm{~m}^{2}$ ) based on the slope, aspect and position relative to the surface morphology as reported by Dutoit (1983). If the plot position could not be unambiguously located in this way or if most of the circle area was overgrown by shrubs, no data were taken.

Re-located plots were recorded following the same methods as Dutoit (1983). In order to account for species recorded in 1970 but now existing outside of the plots because of small location shifts, we completed the censuses with inventories of supplementary species growing on the $100 \mathrm{~m}^{2}$ area around the plots (hereafter called extended plots). The 19 plots retained (6 in Seslerion albicantis and 13 in Caricion ferrugineae) were distributed on both sides of the valley, with either an eastern (ENE-SE) or a western (WSW-NW) aspect, and slopes ranging between 22-52 (mean $33.7 \pm 7.6^{\circ}$ ). 
In 1930, Lüdi started an experiment with permanent plots in Schynige to find ways to improve the quality of pastures dominated by Nardus stricta (Lüdi 1936). He set up 340 permanent plots, marked with wooden stakes. Each plot was $1 \mathrm{~m}^{2}$, and plots were grouped into different fertilisation experiments. Sampling frequency varied through time, but 23 control plots were retained that were never fertilized; these were inventoried around 1935 (1932-1935), 1954 (19531954), in 1990 and in 2002. Plant cover was estimated as a percentage, with $0.5 \%$ being the smallest value. All plots had a SSE-aspect with a slope of $20^{\circ}$.

Nomenclature of species follows Aeschimann et al. (1996).

\section{Data analyses}

Three types of problems are frequent in this type of monitoring: mistakes in species identification, overlooked species and inter-observer differences in coverage estimates (e.g., \& Hallam 2002; Klimeš 2003; Vittoz \& Guisan 2007). We limited identification mistakes by aggregating all easily confusable, closely related species into one taxon in all subsequent analyses. There is no way to check for overlooked species and we had to be conscious of differences in data quality. Dutoit (1983) inventoried the plots in Nant by herself in 1970, while our study involved two to three botanists in 2006. The higher sampling effort may have caused an apparent increase in the number of species (Vittoz \& Guisan 2007). In Schynige, Lüdi initially was interested in agronomy and probably did not care much about rare species in the original 1935 inventory. Later on, the plots were re-recorded with more interest in diversity. Plots showed an important, probably artificial, species increase between 1935 and 1954; we thus retained only the 1954, 1990 and 2002 inventories in our analyses. Finally, to be able to compare the data from both regions, estimates by percent in Schynige and in the Braun-Blanquet scale in Nant were converted to the same scale (Table 1).

Table 1 Scales used for plant cover estimates at Vallon de Nant, corresponding values in percentages at Schynige Platte, and the transformations used in the analyses.

\begin{tabular}{ccc}
\hline $\begin{array}{c}\text { Braun-Blanquet scale } \\
\text { in Vallon de Nant }\end{array}$ & $\begin{array}{c}\text { Percents in } \\
\text { Schynige Platte }\end{array}$ & $\begin{array}{c}\text { Values used } \\
\text { in analyses }\end{array}$ \\
\hline$r$ & & 0.1 \\
+ & 0.5 & 0.5 \\
1 & $1-5$ & 1 \\
2 & $6-25$ & 2 \\
3 & $26-50$ & 3 \\
4 & $51-75$ & 4 \\
5 & $76-100$ & 5 \\
\hline
\end{tabular}

To avoid giving too much weight to rare species, all subsequent analyses were conducted by excluding species with fewer than three occurrences in all plots and for all years at a site. Correspondence analysis (CA; Bénzécri 1973) was performed in R (R Development Core Team 2007) separately for both sites, to identify possible coherent shifts of the plots between the different inventories (Vittoz \& Hainard 2002; Köhler et al. 2005). The significance of the CA axis was estimated by comparing the observed variance of the axis to a random distribution. One thousand permutations of the species abundance across the plots were performed while keeping prevalence and abundance constant. The significance of temporal shifts in species composition 
along the first three axes of CA was tested by MANOVA by differences of axis scores among inventory dates against the intercept.

In order to interpret vegetation change in terms of environmental factors, ecological indices were calculated for each inventory. These indices were based on species-specific ecological indicator values (Landolt 1977). Plot values were derived as cover-weighted averages of the values of all species recorded during a specific inventory. The values vary between 1 and 5, indicating an increasing demand on light $(\mathrm{L})$, temperature $(\mathrm{T})$, soil humidity $(\mathrm{F})$, humus amount $(\mathrm{H})$, nutrient amount $(\mathrm{N})$ and $\mathrm{pH}(\mathrm{R})$. The plot values were correlated with their position along the first two axes of the CA (Pearson correlation). In Nant we also correlated the axes with plot altitude, slope and calculated radiation (total amount of energy received in June-August related to the slope and aspect; Zimmerann \& Kienast 1999).

Species increasing in abundance were classified into three different groups: $(\mathrm{N})$ new species, absent in the first inventory and present in at least three plots in one of the following inventories; (F) species with an increasing frequency in three or more plots between the first and last inventory; (C) species with an increasing mean cover $\geq 0.3$ between the first and last inventory and present in at least three plots at each inventory. In Schynige, species with strongly fluctuating frequencies between inventories (alternating increase and decrease) were not retained. Similarly, species decreasing in abundance were classified into the following three groups: (d) disappeared species, present in at least three plots in one of the previous inventories and absent in the last one; (f) species with a decreasing frequency in three or more plots between the first and last inventory; (c) species with a decreasing mean cover $\geq 0.3$ between the first and last inventory and present in at least three plots at each inventory. In Nant, the $d$ and $f$ criteria were tested by comparing the original data with the species lists in the extended plots and in Schynige, strongly fluctuating species were discarded. Marginal models for contingency tables (Lang \& Agresti 1994; Lang \& Eliason 1997) were used to test the significance of shifts in the cover-abundance of each species during the time of inventory.

The sociologic affinity, i.e., the affinity for certain habitat types, of decreasing and increasing species was compared with that of the stable species (no change recorded) in each site following affinity specifications in Ellenberg et al. (1991). We then calculated an elevation index for each species following specifications in Binz \& Heitz (1990). For each species, these authors gave the optimum and tolerance in terms of altitudinal belts. Here, we assign a value of 1 for the colline belt, 2 for the montane, 3 for the subalpine and 4 for the alpine belt. The elevation index of a species was calculated as the weighted mean of the altitudinal belts occupied (weight of 2 for belts occupied regularly, 1 for belts rarely occupied). These means were compared using a Wilcoxon test.

Species were finally compared for some important biological traits in growth, reproduction and competition. The growth form was simplified from Pignatti (2005) in 7 categories (phanerophytes, chamaephytes, caespitose hemicryptophytes, hemicryptophytes with rosette, other hemicryptophytes, geophytes and therophytes). Plant maximum height and blooming months (first and last months) were used from Aeschimann et al. (2004). The CSR-strategy (Grime 1979) and the reproduction type (only sexual, mainly sexual, sexual and clonal, mainly clonal) followed the BIOLFLOR database (Klotz et al. 2002). The potential dispersal distance was simplified into three categories (short, medium and long dispersal distance) from the Vittoz \& Engler (2007) classification method. Quantitative variables were compared with t-tests (after a log-transformation for plant maximum height) and categorical variables with $\chi^{2}$-tests. 


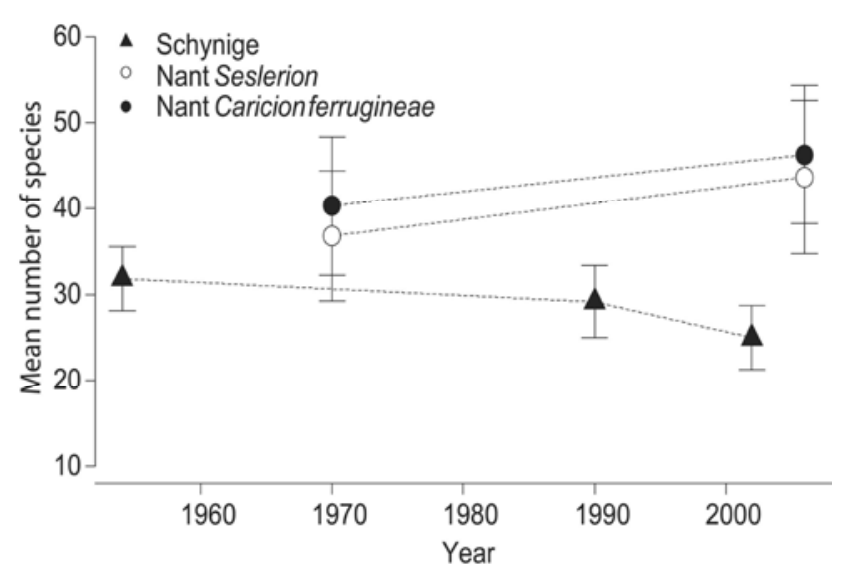

Fig. 2 Mean number of species (with standard deviation) observed in the different surveys at Vallon de Nant (1970 and 2006) and Schynige Platte (1954, 1990 and 2002). The Vallon de Nant data are separated into two vegetation types.

\section{Results}

Between 1970 and 2006 the mean number of species increased from $36.8 \pm 7.6$ to $43.7 \pm 8.9$ in one grassland type (Seslerion albicantis; $\mathrm{p}=0.035$ with a Wilcoxon signed-rank test) and from $40.3 \pm 8.1$ to $46.3 \pm 8.1$ in the other one (Caricion ferrugineae; $p=0.017$ ) in Nant (Fig. 2). 120 species had $\geq 3$ occurrences in all inventories. Conversely, there was a decrease in Schynige $(p<0.001)$ from $31.9 \pm 3.8$ in 1954 to $25.8 \pm 3.8$ species in 2002 (Fig. 2). 68 species had $\geq 3$ occurrences in all inventories.

At both sites, CA revealed unidirectional general trends of vegetation change, with low but significant $(\mathrm{p}<0.001)$ variance explained by the axes (Figs. 3-4). In Nant, the shift was similar for both vegetation types and significant with a MANOVA ( $<<0.001$; Fig. 3$)$. The first CA axis was correlated with increasing temperature, soil humidity and nutrient availability and with decreasing light and $\mathrm{pH}$ (Table 2). The second axis was correlated with increasing temperature and $\mathrm{pH}$ and with decreasing light, soil humidity and humus (Table 2). There was a negative correlation of the first axis with altitude $(\mathrm{r}=-0.472, \mathrm{p}=0.003)$ and slope $(\mathrm{r}=-0.439, \mathrm{p}=0.006)$ and a negative correlation of the second axis with altitude $(\mathrm{r}=-0.419, \mathrm{p}=0.009)$. In Schynige, the plot showed a coherent shift between the 1954 and 2002 inventories, parallel to axis 2 (Fig. 4) and was highly significant with a MANOVA ( $\mathrm{p}<0.001$ for 1954-1990, 1990-2002 and 1954-2002). The first axis of the CA was correlated with increasing temperature and humus and with decreasing light, humidity, nutrients and $\mathrm{pH}$. The second axis was correlated with decreasing light (Table 2). 


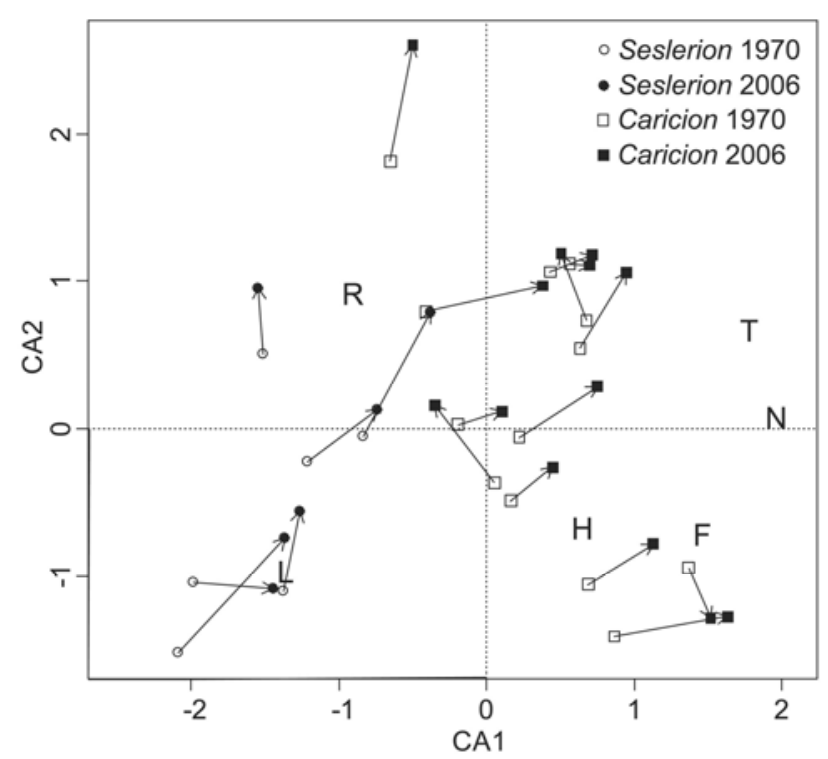

Fig. 3 Correspondence analysis with the relevés of Vallon de Nant. Symbols separate sampling years and vegetation types (Seslerion albicantis and Caricion ferrugineae). Arrows indicate the shift of each plot. The first axis represents $14.9 \%$ of the total variance and the second $8.8 \%$. Both axes are significant $(\mathrm{p}<0.001)$. The ecological indicator values $(\mathbf{L}$ light, $\mathbf{T}$ temperature, $\mathbf{F}$ soil humidity, $\mathbf{H}$ humus amount, $\mathbf{N}$ nutrient amount, $\mathbf{R} \mathrm{pH}$; Landolt 1977) are projected by using the Pearson correlation of the weighted average of each inventory with its position along the two axes (correlation is multiplied by 2 ).

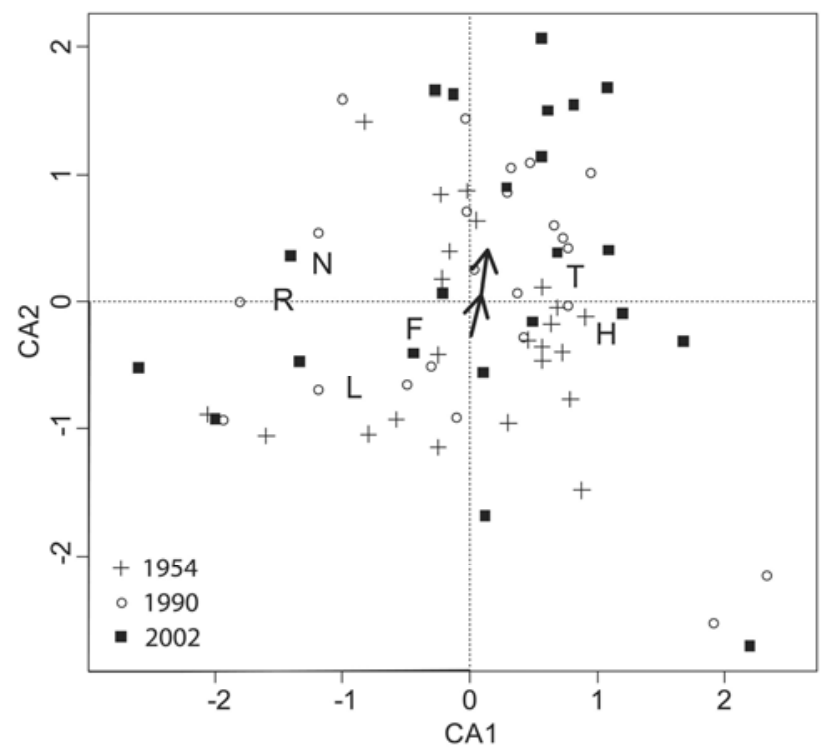

Fig. 4 Correspondence analysis with the relevés of Schynige Platte. Symbols separate sampling years. Arrows indicate the shift of the average position of each year. The first axis represents $9.3 \%$ of the total variance and the second $8.0 \%$. Both axes are significant $(p<0.001)$. Ecological indicator values are as in Fig. 3. 
Table 2 Pearson correlation of mean ecological values (Landolt 1977), with the first two axes of the CA for Vallon de Nant and Schynige Platte. NS not significant, ${ }^{*} \mathrm{p}<0.05,{ }^{* *} \mathrm{p}<0.01,{ }^{* * *}$ $\mathrm{p}<0.001$.

\begin{tabular}{|c|c|c|c|c|}
\hline & \multicolumn{2}{|c|}{ Vallon de Nant } & \multicolumn{2}{|c|}{ Schynige Platte } \\
\hline & Axis 1 & Axis 2 & Axis 1 & Axis 2 \\
\hline$\overline{\text { Light (L) }}$ & $-0.710^{\star \star \star}$ & $-0.511^{\star \star}$ & $-0.489^{\star \star \star}$ & -0.330 ** \\
\hline Temperature $(\mathrm{T})$ & $0.858^{\star \star \star}$ & $0.339 *$ & $0.378^{\star \star}$ & $0.105^{\mathrm{NS}}$ \\
\hline Soil humidity (F) & $0.698^{\star \star \star}$ & $-0.352^{\star}$ & $-0.256^{*}$ & $-0.096^{\mathrm{NS}}$ \\
\hline Humus amount $(\mathrm{H})$ & $0.287^{\mathrm{NS}}$ & $-0.333^{*}$ & $0.492^{\star \star \star}$ & $-0.119^{N S}$ \\
\hline Nutrient amount (N) & $0.944^{\star \star *}$ & $0.041^{N S}$ & $-0.619 * \star *$ & $0.155^{\mathrm{NS}}$ \\
\hline $\mathrm{pH}(\mathrm{R})$ & $-0.491^{* *}$ & $0.462^{\star *}$ & $-0.772^{\star \star \star}$ & $0.019^{\mathrm{NS}}$ \\
\hline
\end{tabular}

Thirty-three species were classified as increasing and 13 as decreasing in Nant (App. 2 and 3). Centaurea montana was the only new species in the plots (already present in the valley in 1970), Heracleum sphondylium, Galium anisophyllon, Rubus saxatilis and Carex ornithopoda had the highest frequency increases and Trifolium medium, Brachypodium pinnatum and Calamagrosits varia had the highest cover increases, although none were significant with marginal models. Only Trifolium badium disappeared from the plots; no species decreased in frequency and Carex sempervirens, Alchemilla conjuncta aggr. and Hedysarum hedysaroides showed the most pronounced cover decreases (significant with marginal models only for Carex sempervirens). Increasing species were mainly associated with fallows, wood edges or were those that had a wide ecological tolerance, while decreasing species were mainly associated with alpine grasslands (Fig. 5). Altogether, increasing species had a lower elevation index than did decreasing species (Fig. 6) and were taller than stable species, while stable species were taller than decreasing species (Table 3, Fig. 7). Apart from $\geq 40 \%$ of species with a CSR-strategy in both increasing and decreasing species groups, the increasing group was dominated by C-species (C or CS) while the decreasing group was dominated by S-species (CS or S; Table 3, Fig. 8). All other compared biological traits were not significant (Table 3).
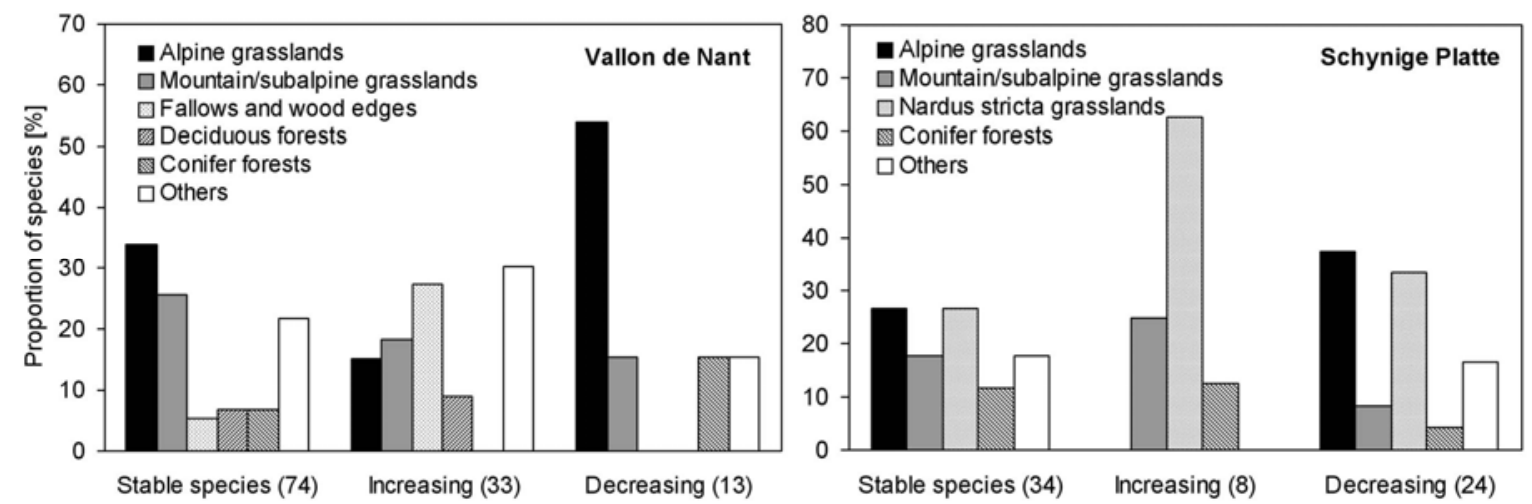

Fig. 5 Sociologic affinity (Ellenberg et al. 1991) of the species at Vallon de Nant (left) and Schynige Platte (right) for the complete list of observed species (all species), as well as the increasing and the decreasing species. The number of species considered in each category is between brackets. 
Eight species were classified as increasing and 24 as decreasing in Schynige (App. 4 and 5), and only Rhinanthus alectorolophus was new in our plots. It was already present in Schynige in one fertilized experimental plot in 1935, but showed a very strong progression in the last decade. The other frequency increases were weaker, but Nardus stricta and Gentiana purpurea showed a significant cover increase with marginal models (App. 4). Of the species that disappeared, Vaccinium vitis-idaea and Euphrasia minima had the highest original frequencies and 14 species were half (or less) as frequent (App. 5). Calluna vulgaris, Arnica montana and Potentilla erecta cover decreased significantly. Alpine grassland species decreased and there was a turnover among species associated with Nardus stricta grasslands (Fig. 5). There was no significant difference in the elevation index of increasing or decreasing species (Fig. 6) and no differences in the biological traits that were considered (Table 3).

Table 3 Differences ( $p$-values) in biological trait distributions between stable, decreasing and increasing species at Vallon de Nant and Schynige Platte (see Location and methods for the analyses).

\begin{tabular}{|c|c|c|c|c|c|c|}
\hline \multirow[b]{2}{*}{ Number of species } & \multicolumn{3}{|c|}{ Vallon de Nant } & \multicolumn{3}{|c|}{ Schynige Platte } \\
\hline & $\begin{array}{c}\text { Stable vs } \\
\text { Decreasing } \\
74 / 13\end{array}$ & $\begin{array}{c}\text { Stable vs } \\
\text { Increasing } \\
74 / 33\end{array}$ & $\begin{array}{c}\text { Decreasing vs } \\
\text { Increasing } \\
13 / 33\end{array}$ & $\begin{array}{c}\text { Stable vs } \\
\text { Decreasing } \\
34 / 24\end{array}$ & $\begin{array}{c}\text { Stable vs } \\
\text { Increasing } \\
34 / 8\end{array}$ & $\begin{array}{c}\text { Decreasing vs } \\
\text { Increasing } \\
24 / 8\end{array}$ \\
\hline Maximum height & 0.007 & 0.040 & 0.000 & 0.298 & 0.427 & 0.146 \\
\hline First month of blooming & 0.647 & 0.952 & 0.697 & 0.932 & 0.335 & 0.391 \\
\hline Sexual vs clonal reproduction & 0.948 & 0.069 & 0.444 & 0.599 & 0.537 & 0.765 \\
\hline Dispersal distance (3 classes) & 0.225 & 0.430 & 0.139 & 0.861 & 0.360 & 0.452 \\
\hline
\end{tabular}

\section{Discussion}

\section{Vegetation changes}

Observed changes at both sites were minor, with low variance explained by axes in both CA plots (Figs. 3-4). Structuring and dominant species remained the same at both sites with fluctuations only for the cover values of dominant species and frequency changes of low cover species. Mean species richness increase per plot was $16 \%$ in Nant over the 36-year survey. This significant increase is probably partly due to better sampling (2-3 botanists in 2006 instead of one in 1970; Vittoz \& Guisan 2007). Conversely, there was a significant (22\%) decrease in species richness in Schynige over 48 years (Fig. 2). In both regions, only one new species was recorded in the plots sampled, while one species was lost in Nant and six were lost in Schynige (App. 2-5). In comparison, the mean number of species increased by 26\% between 1983 and 2003 on ten alpine-nival summits in the Alps (Walther et al. 2005a), by 11.8\% between 1994 and 2004 in 362 plots in the Austrian Alps (2,900-3,450 m a.s.1.; Pauli et al. 2007) and by 27-42\% between 1988 and 2003 in 48 plots in German alpine grasslands (1,800-2,350 m a.s.1.; Kudernatsch et al. 2005). Although not directly comparable, these values indicate that the subalpine sites of Schynige and Nant did not show a species richness increase comparable to what was previously observed in the alpine-nival levels in recent decades at other locations. 

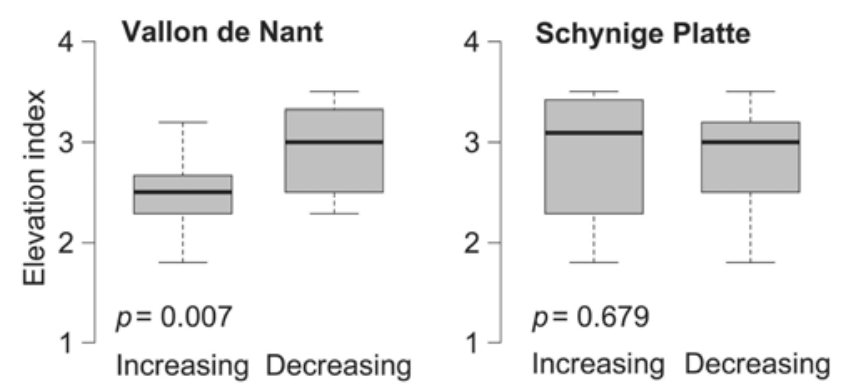

Fig. 6 Elevation index of the increasing and decreasing species at Vallon de Nant (left) and Schynige Platte (right). The central lines are the medians, the boxes represent the second and third quartiles and horizontal lines indicate the outliers. The p-values are from the Wilcoxon test.

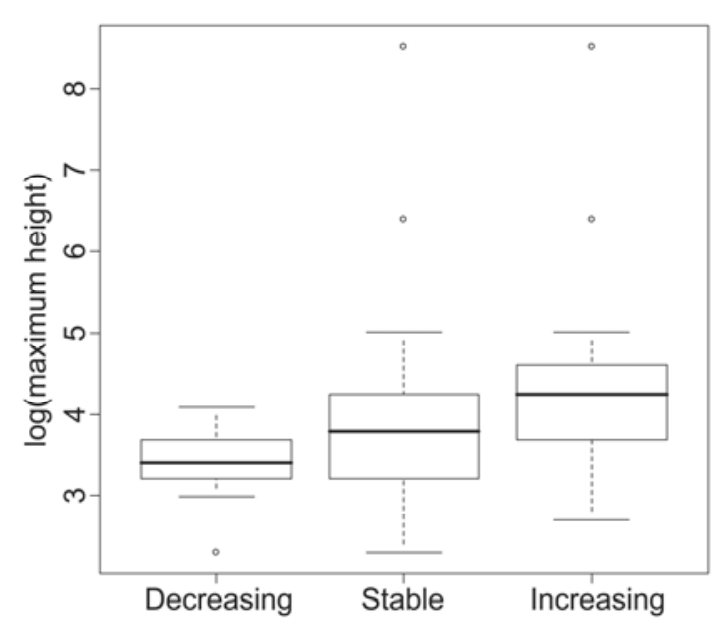

Fig. 7 Maximum height (following Aeschimann et al. 2004) of the decreasing, stable and increasing species at Vallon de Nant (logarithm of the height in cm; box-plots as in Fig. 6).

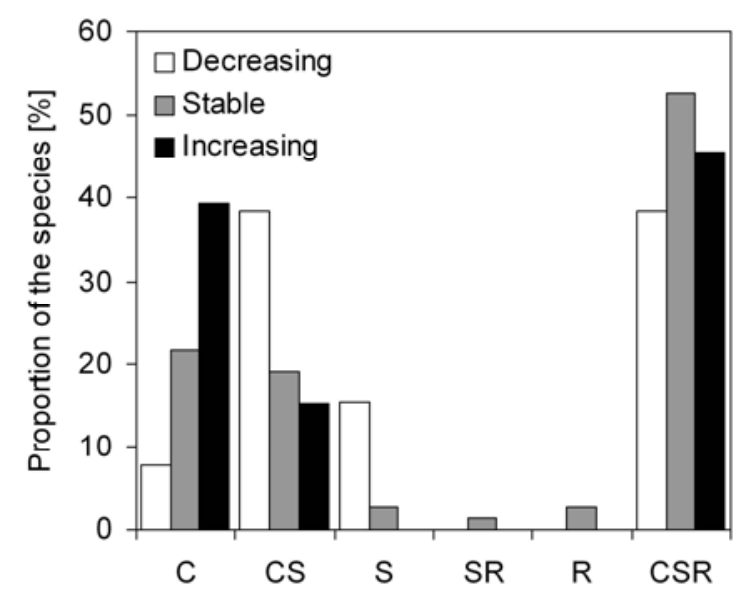

Fig. 8 Distribution of the CSR-strategy (following Klotz et al. 2002) among the decreasing, stable and increasing species at Vallon de Nant. 
The coherent change observed in the plots in Nant was mainly associated with decreasing light (more shade-preferring species) and increasing temperature according to correlations with ecological indicator values (Table 2, Fig. 3). A large number of increasing species were from fallows and wood edges (e.g., Centaurea montana, Chaerophyllum villarsii and Trifolium medium) or had a wide ecological amplitude. However, among these species, many were also common in abandoned pastures (Astrantia major, Calamagrostis varia, Carex flacca, Gentiana lutea, Rubus saxatilis; Oberdorfer 1990; Mayer \& Grabner 2004). The trends of Brachypodium pinnatum and Trifolium medium were particularly remarkable in this context as these two species are well known efficient colonisers of abandoned grasslands (Mayer \& Grabner 2004; Köhler et al. 2005). This indicates that the main driver behind these changes was probably the abandonment of goat and sheep grazing on the slopes. In correspondence, the species that decreased in Nant were mainly associated with short, alpine grasslands (Figs. 5 and 7), like Trifolium badium, Carex sempervirens, Alchemilla conjuncta aggr., Hedysarum hedysaroides and Anthyllis vulneraria subsp. alpestris. Their decline was probably driven largely by the increasing density of taller (Fig. 7) and more competitive (Fig. 8) subalpine plants and fallow species, which were no longer restrained by livestock grazing (Pöyri et al. 2006). The higher elevation index of decreasing species compared to the increasing species (Fig. 6) has two possible explanations: (i) The warmer climate of recent decades may have favoured lowland species, as indicated by some of the increasing species which are around their upper altitudinal distribution limit in the region (Brachypodium pinnatum, Trifolium medium, Vincetoxicum hirundinaria; Binz \& Heitz 1990 and data from the MODIPLANT project (Guisan 2005; Randin et al. 2006), (ii) But species from alpine grasslands are generally able to grow in the subalpine belt (Binz \& Heitz 1990) when grazing maintains low grass height, but they are naturally limited by forests or taller plants. Hence, the decrease of elevation index may correspond to a return to a natural situation after pasture abandonment. Management and climate can have similar effect on the elevation index and experiments would be necessary to clarify the observations.

In Schynige, changes were unidirectional and significant as well, but weak along axis 2, which had a low explained variance (Fig. 4). Rhinanthus alectorolophus showed the most important increase, especially pronounced after 1990. Future inventories will determine if this is a real trend or only a temporary fluctuation, but this species is at its upper altitudinal distribution limit (Binz \& Heitz 1990) at the monitoring plots and the high climate warming rate of the last decades (App. 1; Rebetez \& Reinhard in press) may have triggered this recent development. As in Nant, many decreasing species belonged to the alpine grassland group (e.g., Euphrasia minima, Soldanella alpina) or had low foliage distribution (e.g., Selaginella selaginoides, Plantago alpina, Crepis aurea, Arnica montana; App. 5), although no significant change was recorded for plant height (the available data corresponded to the maximum plant height but not to the foliage position). These low plants may have suffered from the change from annual grazing to biannual mowing, corresponding with increasing grass density (Fischer \& Wipf 2002) and mean height (at least every two years). This is corroborated by the decreasing light conditions detected with ecological values (Table 2, Fig. 4), although this result should be considered cautiously because of the low variance explained by the axis. However, it is possible that the disappearance of Euphrasia minima is linked to the increase of Rhinanthus alectorolophus, as both are unspecialized hemi-parasites (Hartl \& Wagenitz 1975) and Euphrasia was situated at its lower altitudinal limit (Binz \& Heitz 1990). Phoenix \& Press (2005) hypothesized that the wide host range of hemi-parasites like Rhinanthus may facilitate their migration under warmer conditions. 


\section{Climate change and community composition}

The influence of climate change on vegetation has already been shown with numerous examples (see Walther et al. 2002; Parmesan \& Yohe 2003 for reviews). Important changes or quick reactions were recorded when the colonising species could occupy sparsely covered areas, other available ecological niches, or when they were taller than the original species. Available space is found on alpine-nival summits in the Alps where a high plant diversity increase was recorded during the $20^{\text {th }}$ century (e.g., Hofer 1992; Grabherr et al. 1994; Walther et al. 2005a; Vittoz et al. 2006). Climate is the major factor limiting their altitudinal distribution; the species are colonising areas with low plant cover. Mistletoe (Viscum album subsp. austriacum), a parasite of Pinus sylvestris, climbed $200 \mathrm{~m}$ during the $20^{\text {th }}$ century in the Swiss Central Alps (Dobbertin et al. 2005). Pine trees exist at about $500 \mathrm{~m}$ above the current mistletoe distribution and no other parasite is present. The ecological niche is thus free to be colonised under the new climatic conditions. Similarly, Ilex aquifolium, a forest undergrowth species, spread recently to the north in Scandinavia (Walther et al. 2005b). Its quick shift was facilitated by its presence in gardens and probably also by the low density of forest undergrowth. Ilex aquifolium is indeed one of the rare very shade tolerant, tall shrubs in Central Europe (Landolt 1977) that can colonise this niche.

Colonisation by taller species was recorded by Braun-Blanquet (1975), who monitored a snowbed community in the Alps for 26 years. Plant diversity and cover increased over time, with a shift from moss-dominated vegetation to flowering plants. A similar structural change was recorded in summer warming experiments in Alaskan arctic tundra, with shrub cover and size increasing at the expense of shade sensitive lichens and bryophytes (Hollister et al. 2005b; Wahren et al. 2005; Tape et al. 2006). The observed upward shift of the altitudinal treeline ecotone in many mountain regions (e.g., Kullman 2001; Camarero \& Gutierrez 2004; Vittoz et al. 2008a) proceeds identically with the substitution of low alpine grasses by trees.

Plant composition changes inside a community without structural changes are less common. These have been observed in South Switzerland forests, where introduced, evergreen broadleaved species (Cinnamomum glanduliferum, Laurus nobilis, Prunus laurocerasus, Trachycarpus fortunei) are replacing native deciduous species following a lengthening of the growing season and a strong decrease in the number of frost days (Gianoni et al. 1988; Walther 2002; Walther et al. 2007). Another species replacement was recorded in mountain forests of Northern Spain, where Quercus ilex has been invading degraded stands of Fagus sylvatica because of warmer temperatures (Peñuelas \& Boada 2003).

In contrast to these studies recording major changes, our results show that changes under climate warming have until now been limited in semi-natural subalpine grasslands. A similar low rate of change was found in a four year warming experiment in a subalpine grassland in West-Central Colorado (Price \& Waser 2000). The authors explained this result (compared to the pronounced responses recorded in warming experiments in the Arctic tundra) by summer dry conditions cancelling out the effects of earlier snowmelt. But drought is not a problem in the Northern Alps, and the small changes with climate warming are better explained by interactions between plants. Kikvidze et al. (2001) and Callaway et al. (2002) observed that competition dominates interactions between species in subalpine grasslands, where conditions are less physically stressful than in alpine grasslands, where facilitation is more important. In Nant and Schynige, it is probable that newly arrived species, close to their physiological limit for temperature, have to germinate and grow in the middle of dense plant cover, and that many of them (e.g., Poaceae and Cyperaceae) with high longevity slow down species replacement (Theurillat \& Guisan 2001). 
This strongly limits their survival and thus the rate of change in subalpine grasslands. However, an insufficient dispersal of low subalpine or montane plants to colonise the studied sites (Malcolm et al. 2002), due to ecological (e.g., large forests) or topographical obstacles, may partly explain the grassland stability. By comparison, the quick migration of Ilex aquifolium (Walther et al. 2005b) and the evergreen broad-leaved species (Walther 2002) were facilitated by human introductions in gardens.

Competition also restricts alpine species growth in subalpine grasslands (Choler et al. 2001), although climate is not directly an obstacle. Indeed, alpine and arctic plants respond to warmer temperatures by changing resource allocation toward reproductive organs rather than by increasing growth (Hollister et al. 2005a). This interpretation agrees with the proposition that alpine plants will be competitively displaced by taller subalpine plants under climate warming (Theurillat \& Guisan 2001).

\section{Future trends in these subalpine grasslands}

Both study sites will probably diverge in the future if land use similar to that during recent decades is maintained. After completely abandoning grazing in Nant, future colonisation by shrubs and trees is unavoidable, except in some snow avalanche pathways. Evidence of this evolution is already present (increasing Salix appendiculata and Larix decidua), and forest shadow will exclude the remaining alpine plants. In Schynige, however, mowing will prevent such colonisation. Either changes will be observed progressively in the future with isolated colonisation of new species and the disappearance of others, or vegetation composition will be more and more decoupled from climatic conditions. Experiments and data are insufficient to determine precisely what will happen, but major quick changes may follow disturbances which open gaps in the grassland. For example, population outbreaks of field voles open such gaps and exceptional climatic droughts may kill large numbers of the dominant species (van der Maarel 1996; Gigon 1997).

\section{Conclusion}

Species colonisation induced by climate warming may be rapid on high mountain summits with incomplete plant ground cover or when there is a clear structural change, like trees invading alpine grasslands. However, the invasion of new herbaceous species into the subalpine grasslands that we studied was obviously hampered by the density of resident species; both regions showed only limited changes in vegetation composition. At Vallon de Nant, abandonment of grazing favoured plants from fallow and wood edge communities, whose taller size shadowed lowgrowing alpine species. However, climate change cannot be excluded as an influence, because some of the increasing species are close to their highest distribution limit. At Schynige Platte, mowing replaced grazing; the weak observed changes appear to be mainly associated with higher plant density and height that caused species with low foliage, e.g., the alpine plants, to decrease or disappear. However, climate change may be responsible for the development of Rhinanthus alectorolophus, perhaps to the detriment of Euphrasia minima as both are hemi-parasites. In sum, the observed changes in vegetation composition agreed with Körner's hypothesis (2005) that future vegetation changes in mountain areas will be influenced more by anthropogenic management than by climate change. Supplementary data from other subalpine grasslands are necessary to determine whether this stability is a general trend. 


\section{Acknowledgments}

This research has been supported by the Federal Office for the Environment FOEN

(Switzerland), Centre de conservation de la faune et de la nature (Canton de Vaud) and Fondation Audemars Piguet. We are grateful to Prof. Jérôme. Goudet and Dr. Karl Hülber for their advice in statistical analysis, Dr. Stefan Dullinger and two anonymous reviewers for their useful comments on earlier versions of the manuscript.

\section{Bibliography}

Aeschimann D, Heitz C, Palese R, Perret P, Moser M (1996) Index synonymique de la Flore de Suisse. Documenta Floristicae Helvetiae 1. Centre du Réseau Suisse de Floristique, Geneva, $317 \mathrm{pp}$.

Aeschimann D, Lauber K, Moser DM, Theurillat J-P (2004) Flora alpina. Belin, 3 vol.

Bätzing W (1991) Die Alpen. Entstehung und Gefährdung einer europäisch Kulturlandschaft. Beck Verlag, München, 287 pp.

Bénzécry J.-P. 1973. L'analyse des correspondances. L'analyse des données 2, Dunod, Paris, 632 pp.

Binz A, Heitz C (1990) Schul- und Exkursionsflora für die Schweiz. $19^{\text {th }}$ Ed., Schwabe \& Co, Basel, 659 pp.

Braun-Blanquet J (1964) Pflanzensoziologie. Grundzüge der Vegetationskunde. $3^{\text {rd }}$ Ed., Springer, Wien/New-York, 865 pp.

Braun-Blanquet J (1957) Ein Jahrhunder Florenwandel am Piz Linard (3414 m). Bulletin du Jardin Botanique Etat Bruxelles, Volume jubilaire W. Robyns, 221-232.

Braun-Blanquet J (1975) Fragmenta phytosociologica raetica I. Die Schneebodengesellschaften (Klasse der Salicetea herbaceae). Jahresbericht der Naturforschenden Gesellschaft Graubündens, 96, 42-71.

Burke MJW, Grime JP (1996) An experimental study of plant community invasibility. Ecology, 77, 776-790.

Callaway RM, Brooker RW, Choler P et al. (2002) Positive interactions among alpine plants increase with stress. Nature, 417, 844-848.

Camarero JJ, Gutiérrez E (2004) Pace and pattern of recent treeline dynamics: response of ecotones to climatic variability in the Spanish Pyrenees. Climatic Change, 63, 181-200.

Choler P, Michalet R, Callaway RM (2001) Facilitation and competition on gradients in alpine plant communities. Ecology, 82, 3295-3308.

D'Arrigo R, Jacoby GC, Fung IY (1987) Boreal forests and atmosphere-biosphere exchange of carbon dioxide. Nature, 329, 321-323. 
Dirnböck T, Dullinger S, Grabherr G (2003) A regional impact assessment of climate and landuse change on alpine vegetation. Journal of Biogeography, 30, 401-417.

Dobbertin M, Hilker N, Rebetez M, Zimmermann NE, Wohlgemuth T, Rigling A (2005) The upwart shift of pine mistletoe (Viscum album ssp. austriacum) in Switzerland - The result of climate warming? International Journal of Biometeorology, 50, 40-47.

Dullinger S, Dirnböck T, Greimler J, Grabherr G (2003) A resampling approach for evaluating effects of pasture abandonment on subalpine plant species diversity. Journal of Vegetation Science, 14, 243-252.

Dullinger S, Dirnböck T, Köck R, Hochbichler E, Englisch T, Sauberer N, Grabherr G (2005) Interactions among tree-line conifers: differential effects of pine on spruce and larch. Journal of Ecology, 93, 948-957.

Dutoit A (1983) La végétation de l'étage subalpin du vallon de Nant. Section protection de la nature et des sites et Conservation de la faune du canton de Vaud, Lausanne, 128 pp.

Ellenberg H, Weber HE, Düll R, Wirtz V, Werner W, Paulissen D (1991) Zeigerwerte von Pflanzen in Mitteleuropa. Scripta Geobotanica 18, Goltze KG, Göttingen, 248 pp.

Fischer M, Wipf S (2002) Effect of low-intensity grazing on the species-rich vegetation of traditionally mown subalpine meadows. Bilogical Conservation, 104, 1-11.

Gianoni G, Carraro G, Klötzli F (1988) Thermophile, an laurophyllen Pflanzearten reiche Waldgesellschaften im hyperinsubrischen Seenbereich des Tessins. Berichte des Geobotanisches Institutes ETH, Stiftung Rübel, in Zürich, 54, 164-180.

Gigon A (1997) Fluktuationen des Deckungsgrades und die Koexistenz von Pflanzenarten in Trespen-Halbtrockenrasen (Mesobromion). Phytocoenologia, 27, 275-287.

Grabherr G, Gottfried M, Pauli H (1994) Climate effects on mountain plants. Nature, 369, 448.

Grime JP (1979) Plant strategies and vegetation processes. John Wiley \& Sons, Chichester, 222 pp.

Guisan A (2005) Niche-based models as tools to assess climate change impact on the distribution and diversity of plants in mountain reserves. In: $2^{\text {nd }}$ and $3^{\text {rd }}$ GLOCHAMORE workshops (ed Mountain Research Initiative), pp. 80-91. UNESCO, Paris, L'Aquila and Granada.

Guisan A, Theurillat J-P (2000) Assessing alpine plant vulnerability to climate change: A modeling perspective. Integrated Assessment, 1, 307-320.

Guisan A, Thuiller W (2005) Predicting species distribution: offering more than simple habitat models? Ecology Letters, 8, 993-1009.

Guisan A, Zimmermann NE (2000) Predictive habitat distribution models in ecology. Ecological Modelling, 135, 147-186.

Hartl D, Wagenitz G (1975) Dycotyledones, 4. Teil. Illustrierte Flora von Mitteleuropa 6 (1), $2^{\text {nd }}$ ed, Paul Parey, Berlin, 631 pp.

Hegg O (1992) Long term influence of fertilization in a Nardetum. The experimental field of Dr. Werner Lüdi on the Schynige Platte. Vegetatio, 103, 133-134. 
Hofer HR (1992) Veränderungen in der Vegetation von 14 Gipfeln der Berninagebietes zwischen 1905 und 1985. Berichte des geobotanischen Institut ETH Stiftung Rübel Zürich, 58, 3954.

Hollister RD, Webber PJ, Bay C (2005a) Plant response to temperature in Northern Alaska: implications for predicting vegetation change. Ecology, 86, 1562-1570.

Hollister RD, Webber PJ, Tweedie CE (2005b) The response of Alaskan arctic tundra to experimental warming: differences between short- and long-term responses. Global Change Biology, 11, 525-536.

Huntley B (1991) How plant respond to climate change: migration rates, individualism and the consequences for plant communities. Annals of Botany, 67, 15-22.

Kikvidze Z, Khetsuriani L, Kikodze D, Callaway RM (2001) Facilitation and interference in subalpine meadows of the central Caucasus. Journal of Vegetation Science, 12, 833-838.

Klanderud K, Birks HJB (2003) Recent increases in species richness and shifts in altitudinal distributions of Norwegian mountain plants. The Holocene, 13, 1-6.

Klimeš L (2003) Scale-dependent variation in visual estimates of grassland plant cover. Journal of Vegetation Science, 14, 815-821.

Klotz S, Ingolf K, Durka W (2002) BIOLFOR - Eine Datenbank mit biologisch-ökologishen Merkmalen zur Flora von Deutschland. Schriftenreihe für Vegetationskunde 38, Bundesamt für Naturschutz, Bonn, 334 pp.

Köhler B, Gigon A, Edwards PJ, Krüsi B, Langenauer R, Lüscher A, Ryser P (2005) Changes in the species composition and conservation value of limestone grasslands in Northern Switzerland after 22 years of contrasting managements. Perspectives in Plant Ecology Evolution and Systematics, 7, 51-67.

Körner C (2005) The green cover of mountains in a changing environment. In: Global change and mountain regions (eds Huber UM, Bugmann HKM, Reasoner MA), pp. 367-375. Springer, Dordrecht.

Kudernatsch T, Beck S, Krenzer M et al. (2005) Recent changes in species composition and species richness of alpine grasslands in Berchtesgaden Biosphere Reserve and National Park. In: 2nd and 3rd GLOCHAMORE workshops (ed Mountain Research Initiative), pp. 103-115. UNESCO, Paris, L'Aquila and Granada.

Kullman L (2001) 20th century climate warming and tree-limit rise in the southern Scandes of Sweden. AMBIO, 30, 72-80.

Landolt E (1977) Ökologische Zeigerwerte zur Schweizer Flora. Veröffentlichungen des Geobotanischen Institutes der ETH, Stiftung Rübel, Zürich, 64, 1-208.

Lang JB, Agresti A (1994) Simultaneously modeling joint and marginal distributions of multivariate categorical responses. Journal of the American Statistical Association, 89, 625-632.

Lang JB, Eliason JR (1997) The application of association-marginal models to the study of social mobility. Sociological Methods and Research, 26, 183-213. 
Lüdi W (1936) Experimentelle Untersuchungen an alpiner Vegetation. Berichte der Schweizerischen Botanischen Gesellschaft, 46, 632-681.

Malcolm JR, Markham A, Neilson RP, Garaci M (2002) Estimated migration rates under scenarios of global climate change. Journal of Biogeography, 29, 835-849.

Mayer R, Grabner S (2004) Vegetation pattern and succession processes in cultivated and abandoned subalpine grasslands in the Valsertal (North Tyrol/Austria). Tuexenia, 24, 227245.

Motta R, Nola P (2001) Growth trends and dynamics in sub-alpine forest stands in the Varaita Valley (Piedmont, Italy) and their relationships with human activities and global change. Journal of Vegetation Science, 12, 219-230.

Oberdorfer E (1990) Pflanzensoziologische Exkursionsflora. $6^{\text {th }}$ ed. Ulmer, Stuttgart, $1050 \mathrm{pp}$.

Parmesan C, Yohe G (2003) A globally coherent fingerprint of climate change impacts across natural systems. Nature, 421, 37-42.

Pauli H, Gottfried M, Reiter K, Klettner C, Grabherr G (2007) Signals of range expansions and contractions of vascular plants in the high Alps: observations (1994-2004) at the GLORIA master site Schrankogel, Tyrol, Austria. Global Change Biology, 13, 147-156.

Pearson RG, Dawson TP (2003) Predicting the impacts of climate change on the distribution of species: are bioclimatic envelope models useful? Global Ecology and Biogeography, 12, 361-371.

Peñuelas J, Boada M (2003) A global change-induced biome shift in the Montseny mountains (NE Spain). Global Change Biology, 9, 131-140.

Phoenix GK, Press MC (2005) Effects of climate change on parasitic plants: the root hemiparasitic Orobanchaceae. Folia Geobotanica, 40, 205-216.

Pignatti S (2005) Valory di bioindicazione delle piante vascolari della flora d'Italia. BraunBlanquetia, 39, 1-97.

Pöyry, J, Luoto, M, Paukkunen, J, Pykälä, J, Raatikainen, K, Kuussaari, M (2006) Different responses of plants and herbivore insects to a gradient of vegetation height: an indicator of the vertebrate grazing intensity and successional age. Oikos, 115, 401-412.

Price MV, Waser NM (2000) Responses of subalpine meadow vegetation to four years of experimental warming. Ecological Applications, 10, 811-823.

R Development Core Team (2007) R: A language and environment for statistical computing. $\mathrm{R}$ Foundation for Statistical Computing, Vienna, Austria. http://www.R-project.org

Randin CF, Dirnböck T, Dullinger S, Zimmermann NE, Zappa M, Guisan A (2006) Are nichebased species distribution models transferable in space? Journal of Biogeography, 33, 1689-1703.

Rebetez M, Reinhard M (2008) Monthly air temperature trends in Switzerland 1901-2000 and 1975-2004. Theoretical and Applied Climatology, 91, 27-34.

Scott WA, Hallam CJ (2002) Assessing species misidentification rates through quality assurance of vegetation monitoring. Plant Ecology, 165, 101-115. 
Sebastia MT (2007) Plant guilds drive biomass response to global warming and water availability in subalpine grassland. Journal of Applied Ecology, 44, 158-167.

Silvertown J, Holtier S, Johnson J, Dale P (1992) Cellular automaton models of interspecific competition for space - the effect of pattern on process. Journal of Ecology, 80, 527-534.

Tape K, Sturm M, Racine C (2006) The evidence for shrub expansion in Northern Alaska and the Pan-Arctic. Global Change Biology 12, 686-702.

Theodose TA, Bowman WD (1997) The influence of interspecific competition on the distribution of an alpine graminoid: evidence for the importance of plant competition in an extreme environment. Oikos, 79, 101-114.

Theurillat J-P, Guisan A (2001) Potential impact of climate change on vegetation in the European Alps: a review. Climatic Change, 50, 77-109.

Tinner W, Theurillat J-P (2003) Uppermost limit, extent, and fluctuations of the timberline and treeline ecocline in the Swiss Central Alps during the past 11,500 years. Arctic, Antarctic and Alpine Research, 35, 158-169.

van der Maarel E (1996) Pattern and process in the plant community: fifty years after A.S. Watt. Journal of Vegetation Science, 7, 19-28.

van Wijk MT, Clemmensen KE, Shaver GR et al. (2004) Long-term ecosystem level experiments at Toolik Lake, Alaska, and at Abisko, Northern Sweden: generalizations and differences in ecosystem and plant type responses to global change. Global Change Biology, 10, 105123.

Vittoz P, Bodin J, Ungricht S, Burka CA, Walther G-R (2008b) One century of vegetation change on Isla Persa, a nunatak in the Bernina massif in the Swiss Alps. Journal of Vegetation Sciences, 19, 671-680.

Vittoz P, Engler R (2007) Seed dispersal distances: a typology based on dispersal modes and plant traits. Botanica Helvetica, 117, 109-124.

Vittoz P, Guisan A (2007) How reliable is the monitoring of permanent vegetation plots? A test with multiple observers. Journal of Vegetation Sciences, 18, 413-422.

Vittoz P, Hainard P (2002) Impact of free-range pigs on mountain pastures in the Swiss Jura. Applied Vegetation Science, 5, 247-254.

Vittoz P, Jutzeler S, Guisan A (2006) Flore alpine et réchauffement climatique: observation de trois sommets valaisans à travers le 20ème siècle. Bulletin de la Murithienne, 123/2005, 49-59.

Vittoz P, Rulence B, Largey T, Freléchoux F (2008a) Effects of climate and land-use change on the establishment and growth of cembran pine (Pinus cembra L.) over the altitudinal treeline ecotone in the Central Swiss Alps. Arctic Antarctic and Alpine Research, 40, 225232.

Wahren CHA, Walker MD, Bret-Harte MS (2005) Vegetation responses in Alaskan arctic tundra after 8 years of a summer warming and winter snow manipulation experiment. Global Change Biology, 11, 537-552.

Walther G-R (2002) Weakening of climatic constraints with global warming and its consequences for evergreen broad-leaved species. Folia Geobotanica, 37, 129-139. 
Walther G-R, Beißner S, Burga CA (2005a) Trends in the upward shift of alpine plants. Journal of Vegetation Science, 16, 541-548

Walther G-R, Berger S, Sykes MT (2005b) An ecological „footprint“ of climate change. Proceedings of the Royal Society B, 272, 1427-1432.

Walther G-R, Gritti ES, Berger S, Hickler T, Tang Z, Sykes MT (2007) Palms tracking climate change. Global Ecology and Biogeography, 16, 801-809.

Walther G-R, Post E, Convey P et al. (2002) Ecological responses to recent climate change. Nature, 416, 389-395.

Zimmermann NE, Kienast F (1999) Predictive mapping of alpine grasslands in Switzerland: Species versus community approach. Journal of Vegetation Science, 10, 469 - 482. 


\section{Appendices (supplemental archives)}

Appendix 1 Temperature in $20^{\text {th }}$ century in Château-d'Oex (980 m, MeteoSwiss data). The thin line gives the mean annual temperature and the broad line a decadal average.

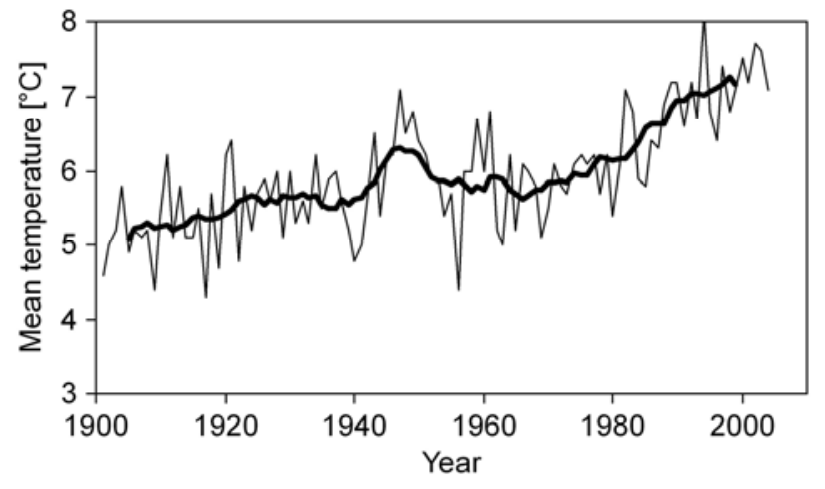

Appendix 2 Increasing species in Vallon de Nant. Change is the type of increase: $\mathbf{N}$ new species, $\mathbf{F}$ frequency increase and $\mathbf{C}$ cover increase.

\begin{tabular}{|c|c|c|c|c|c|c|c|}
\hline \multirow[b]{2}{*}{ Species } & \multicolumn{3}{|c|}{ Frequency } & \multicolumn{3}{|c|}{ Mean cover } & \multirow[t]{2}{*}{ Change } \\
\hline & 1970 & 2006 & Difference & 1970 & 2006 & Difference & \\
\hline Centaurea montana & 0 & 3 & 3 & & 0.10 & 0.10 & $\mathrm{~N}$ \\
\hline Aposeris foetida & 3 & 7 & 4 & 0.50 & 1.01 & 0.51 & $\mathrm{FC}$ \\
\hline Festuca rubra aggr. & 8 & 12 & 4 & 0.94 & 1.26 & 0.32 & FC \\
\hline Brachypodium pinnatum & 3 & 6 & 3 & 0.67 & 1.42 & 0.75 & $\mathrm{FC}$ \\
\hline Chaerophyllum villarsii & 3 & 6 & 3 & 0.50 & 0.95 & 0.45 & $\mathrm{FC}$ \\
\hline Heracleum sphondylium s.l. & 3 & 10 & 7 & 0.50 & 0.43 & -0.07 & $\mathrm{~F}$ \\
\hline Galium anisophyllon & 9 & 15 & 6 & 0.50 & 0.23 & -0.27 & $\mathrm{~F}$ \\
\hline Rubus saxatilis & 2 & 7 & 5 & 0.75 & 0.54 & -0.21 & $\mathrm{~F}$ \\
\hline Carex ornithopoda & 2 & 7 & 5 & 0.50 & 0.27 & -0.23 & $\mathrm{~F}$ \\
\hline Petasites paradoxus & 2 & 6 & 4 & 0.30 & 0.68 & 0.38 & $\mathrm{~F}$ \\
\hline Daphne mezereum & 1 & 5 & 4 & 0.10 & 0.34 & 0.24 & $\mathrm{~F}$ \\
\hline Hieracium murorum aggr. & 10 & 14 & 4 & 0.55 & 0.44 & -0.11 & $\mathrm{~F}$ \\
\hline Campanula scheuchzeri & 2 & 6 & 4 & 0.50 & 0.37 & -0.13 & $\mathrm{~F}$ \\
\hline Ranunculus montanus & 11 & 15 & 4 & 0.64 & 0.48 & -0.16 & $\mathrm{~F}$ \\
\hline Carduus defloratus s.str. & 8 & 12 & 4 & 0.51 & 0.30 & -0.21 & $\mathrm{~F}$ \\
\hline Viola biflora & 1 & 4 & 3 & 0.50 & 0.90 & 0.40 & $\mathrm{~F}$ \\
\hline Salix appendiculata & 1 & 4 & 3 & 0.10 & 0.30 & 0.20 & $\mathrm{~F}$ \\
\hline Laserpitium latifolium & 10 & 13 & 3 & 0.90 & 1.06 & 0.16 & $\mathrm{~F}$ \\
\hline Vincetoxicum hirundinaria & 5 & 8 & 3 & 0.50 & 0.63 & 0.13 & $\mathrm{~F}$ \\
\hline Briza media & 5 & 8 & 3 & 0.50 & 0.58 & 0.08 & $\mathrm{~F}$ \\
\hline Crepis pyrenaica & 10 & 13 & 3 & 0.66 & 0.70 & 0.04 & $\mathrm{~F}$ \\
\hline Gentiana lutea & 4 & 7 & 3 & 0.40 & 0.40 & 0.00 & $\mathrm{~F}$ \\
\hline Astrantia major & 12 & 15 & 3 & 0.88 & 0.87 & -0.01 & $\mathrm{~F}$ \\
\hline Knautia dipsacifolia s.str. & 9 & 12 & 3 & 0.78 & 0.76 & -0.02 & $\mathrm{~F}$ \\
\hline Leucanthemum vulgare aggr. & 16 & 19 & 3 & 0.59 & 0.51 & -0.08 & $\mathrm{~F}$ \\
\hline Alchemilla vulgaris aggr. & 1 & 4 & 3 & 1.00 & 0.80 & -0.20 & $\mathrm{~F}$ \\
\hline Polygonum viviparum & 7 & 10 & 3 & 0.50 & 0.30 & -0.20 & $\mathrm{~F}$ \\
\hline Potentilla erecta & 9 & 12 & 3 & 0.83 & 0.61 & -0.23 & $\mathrm{~F}$ \\
\hline Agrostis stolonifera & 4 & 7 & 3 & 1.25 & 1.01 & -0.24 & $\mathrm{~F}$ \\
\hline Trifolium medium & 4 & 5 & 1 & 0.50 & 1.42 & 0.92 & $\mathrm{C}$ \\
\hline Calamagrostis varia & 16 & 17 & 1 & 2.31 & 2.94 & 0.63 & C \\
\hline Carex flacca & 5 & 7 & 2 & 0.60 & 1.00 & 0.40 & C \\
\hline Larix decidua & 3 & 3 & 0 & 0.37 & 0.67 & 0.30 & C \\
\hline
\end{tabular}


Appendix 3 Decreasing species in Vallon de Nant. The disappearance of species is evaluated between the original census and the extended area of the new census. Change is the type of decrease: $\mathbf{d}$ disappeared species and $\mathbf{c}$ cover decrease. ${ }^{\circ} \mathrm{p}<0.1,{ }^{*} \mathrm{p}<0.05,{ }^{* *} \mathrm{p}<0.01$ for marginal models about mean cover changes.

\begin{tabular}{|c|c|c|c|c|c|c|c|c|c|c|}
\hline \multirow[b]{2}{*}{ Species } & \multicolumn{3}{|c|}{ Frequency (extended plot) } & \multicolumn{3}{|c|}{ Frequency } & \multicolumn{3}{|c|}{ Mean cover } & \multirow[t]{2}{*}{ Change } \\
\hline & 1970 & 2006 & Difference & 1970 & 2006 & Difference & 1970 & 2006 & Difference & \\
\hline Trifolium badium & 3 & 0 & -3 & 3 & 0 & 3 & 0.50 & & & $\mathrm{~d}$ \\
\hline Carex sempervirens & 15 & 18 & 3 & 15 & 16 & 1 & 3.67 & 2.06 & -1.60 & $C^{\star *}$ \\
\hline Alchemilla conjuncta aggr. & 13 & 18 & 5 & 13 & 13 & 0 & 1.27 & 0.46 & -0.81 & c \\
\hline Hedysarum hedysaroides & 3 & 4 & 1 & 3 & 4 & 1 & 1.33 & 0.63 & -0.71 & c \\
\hline Rhinanthus alectorolophus & 9 & 12 & 3 & 9 & 9 & 0 & 1.06 & 0.42 & -0.63 & c \\
\hline Anthyllis vulneraria subsp. alpestris & 8 & 10 & 2 & 8 & 8 & 0 & 1.00 & 0.40 & -0.60 & c \\
\hline Erica carnea & 6 & 7 & 1 & 6 & 4 & -2 & 1.58 & 1.00 & -0.58 & c \\
\hline Trifolium pratense s.str. & 9 & 11 & 2 & 9 & 8 & -1 & 0.94 & 0.40 & -0.54 & c \\
\hline Dryas octopetala & 4 & 4 & 0 & 4 & 3 & -1 & 1.50 & 1.03 & -0.47 & c \\
\hline Linum alpinum & 6 & 12 & 6 & 6 & 6 & 0 & 0.83 & 0.47 & -0.37 & c \\
\hline Polygala chamaebuxus & 10 & 12 & 2 & 10 & 10 & 0 & 0.90 & 0.57 & -0.33 & c \\
\hline Helianthemum nummularium s.I. & 16 & 18 & 2 & 16 & 17 & 1 & 1.60 & 1.29 & -0.31 & c \\
\hline Thesium pyrenaicum & 5 & 7 & 2 & 5 & 2 & -3 & 0.80 & 0.50 & -0.30 & c \\
\hline
\end{tabular}

Appendix 4 Increasing species in Schynige Platte. Change is the type of increase: $\mathbf{N}$ new species, $\mathbf{F}$ frequency increase and $\mathbf{C}$ cover increase. P-values as in appendix 3.

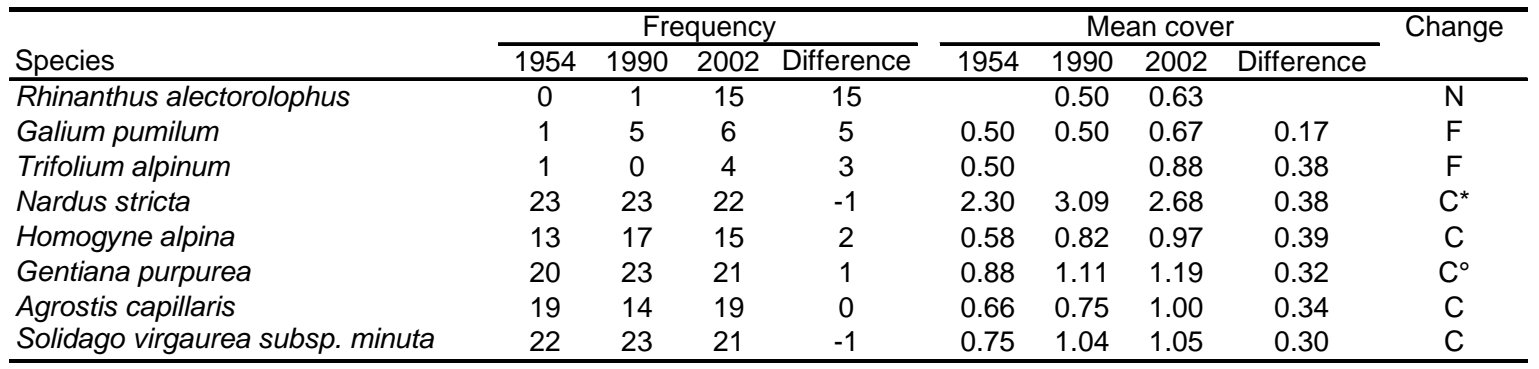


Appendix 5 Decreasing species in Schynige Platte. Change is the type of decrease: $\mathbf{d}$ disappeared species, $\mathbf{f}$ frequency decrease and $\mathbf{c}$ cover decrease. P-values as in appendix 3.

\begin{tabular}{|c|c|c|c|c|c|c|c|c|c|}
\hline \multirow[b]{2}{*}{ Species } & \multicolumn{4}{|c|}{ Frequency } & \multicolumn{4}{|c|}{ Mean cover } & \multirow[t]{2}{*}{ Change } \\
\hline & 1954 & 1990 & 2002 & Difference & 1954 & 1990 & 2002 & Difference & \\
\hline$\overline{\text { Vaccinium vitis-idaea }}$ & 7 & 1 & 0 & -7 & 0.6 & 0.5 & & & $\bar{d}$ \\
\hline Euphrasia minima & 6 & 16 & 0 & -6 & 0.6 & 0.5 & & & $d$ \\
\hline Selaginella selaginoides & 4 & 0 & 0 & -4 & 0.5 & & & & d \\
\hline Carex ornithopoda & 4 & 0 & 0 & -4 & 0.5 & & & & d \\
\hline Gentiana campestris s.l. & 3 & 2 & 0 & -3 & 0.5 & 0.5 & & & d \\
\hline Ligusticum mutellina & 3 & 2 & 0 & -3 & 0.5 & 0.8 & & & d \\
\hline Plantago alpina & 23 & 18 & 9 & -14 & 1.0 & 0.8 & 0.9 & -0.1 & $f$ \\
\hline Crocus albiflorus & 14 & 12 & 1 & -13 & 0.6 & 0.5 & 0.5 & -0.1 & $f$ \\
\hline Festuca rubra aggr. & 20 & 13 & 7 & -13 & 1.1 & 0.8 & 1.1 & 0.1 & $f$ \\
\hline Calluna vulgaris & 20 & 7 & 8 & -12 & 1.2 & 1.1 & 1.0 & -0.2 & $f^{\circ}$ \\
\hline Crepis aurea & 15 & 11 & 3 & -12 & 0.7 & 0.6 & 0.7 & 0.0 & $f$ \\
\hline Viola calcarata & 15 & 8 & 3 & -12 & 0.5 & 0.6 & 0.8 & 0.3 & $f$ \\
\hline Ranunculus montanus aggr. & 15 & 11 & 4 & -11 & 0.7 & 0.5 & 0.5 & -0.2 & $f$ \\
\hline Soldanella alpina & 13 & 12 & 2 & -11 & 0.5 & 0.5 & 0.5 & 0.0 & $f$ \\
\hline Phleum alpinum & 15 & 14 & 4 & -11 & 0.7 & 0.6 & 0.8 & 0.1 & $f$ \\
\hline Pseudorchis albida & 15 & 5 & 4 & -11 & 0.5 & 0.5 & 0.6 & 0.1 & $f$ \\
\hline Avenella flexuosa & 14 & 9 & 6 & -8 & 1.1 & 0.9 & 1.0 & -0.1 & $f$ \\
\hline Pulsatilla alpina s.I. & 11 & 13 & 4 & -7 & 1.2 & 1.2 & 1.4 & 0.1 & $f$ \\
\hline Cerastium fontanum subsp. vulgare & 10 & 4 & 3 & -7 & 0.5 & 0.5 & 0.7 & 0.2 & $f$ \\
\hline Thesium alpinum & 7 & 2 & 2 & -5 & 0.6 & 0.5 & 0.5 & -0.1 & $f$ \\
\hline Leontodon helveticus / hispidus & 22 & 20 & 17 & -5 & 1.1 & 1.0 & 1.1 & -0.1 & $f$ \\
\hline Polygala alpestris & 12 & 7 & 8 & -4 & 0.5 & 0.5 & 0.6 & 0.0 & $f$ \\
\hline Arnica montana & 23 & 23 & 21 & -2 & 2.5 & 1.2 & 1.4 & -1.0 & $C^{\star \star}$ \\
\hline Potentilla erecta & 23 & 23 & 21 & -2 & 1.3 & 1.2 & 1.0 & -0.3 & $c^{*}$ \\
\hline
\end{tabular}

Vittoz et al. 